Original Article

\title{
CHEMICAL CONSTITUENTS, IN VITRO ANTIOXIDANT ACTIVITY, ORAL ACUTE TOXICITY AND LD50 DETERMINATION OF MORINGA OLEIFERA LEAVES
}

\author{
MANAL MORTADY HAMED ${ }^{*}$, ABOELFETOH MOHAMED ABDALLA², MOSAD AHMED GHAREEB', \\ SAID ABDELHALIM SALEH ${ }^{2}$
}

${ }^{1}$ Medicinal Chemistry Department, Theodor Bilharz Research Institute, Kornaish El-Nile, 12411 Warrak El-Hadar, Imbaba (P. 0. 30), Giza, Egypt, ${ }^{2}$ Horticultural Crops Technology Department, National Research Center, Dokki, Cairo, Egypt

Email: manalayman90@yahoo.com

Received: 09 Feb 2017 Revised and Accepted: 31 Mar 2017

\section{ABSTRACT}

Objective: The objective of this study was undertaken to estimate the total phenolic contents (TPCs), in vitro antioxidant of different solvent extracts of $M$. oleifera leaves, oral acute toxicity and $\mathrm{LD}_{50}$ determination of the $85 \%$ methanolic extract as well as the chromatographic isolation and identification of the extract constituents.

Methods: The antioxidant activity of different solvent extracts of Moringa oleifera leaves were estimated using three antioxidant assays and the total phenolic contents (TPCs) were also evaluated using Folin-Ciocalteu's assay. The $n$-BuOH extract undergoes further chromatographic isolation owing to the high antioxidant activity using 2, 2'-diphenyl-1-picrylhydrazyl radical (DPPH) method, which resulted in the isolation of seven compounds.

Results: The results showed that the TPCs values of the tested extracts were varied from 309.52 to $43.28 \mathrm{mg}$ gallic acid equivalent/g dry extract. The reducing power antioxidant activities (RPAA) were $0.434,0.402,0.395,0.149,0.143$ and 0.124 , while the total antioxidant capacity (TAC) values were $316.43,203.35,181.56,86.70,76.62$ and $50.83 \mathrm{mg}$ ascorbic acid equivalent/g dry extract; for $n-\mathrm{BuOH}, \mathrm{EtOAc}, 85 \% \mathrm{MeOH}_{2} \mathrm{H}_{2} \mathrm{O}, \mathrm{CH}_{2} \mathrm{Cl}_{2}$, and pet. ether extracts, respectively. The oral acute toxicity study of the $85 \%$ methanol extracts of M. oleifera and M. peregrina revealed that; their $\mathrm{LD}_{50}$ values were 3458.3 and $4125 \mathrm{mg} / \mathrm{kg}$ respectively, thus the two plants could be classified as slightly toxic in the scale of Hodge and Sterner which reflected their nutrient values as edible plants. The isolated compounds were identified on the basis of their ${ }^{1} \mathrm{H}$ and ${ }^{13} \mathrm{C}$-NMR spectra as; $c i s-p$ coumaric acid 4-O-(2'-O- $\beta$-D-apiofuranosyl)- $\beta$-D-glucopyranoside (1), chlorogenic acid (2), niazirin (3), 3,4-dihydroxy- $\beta$-phenylethoxy-O- $\alpha$-L-

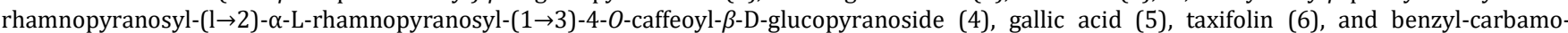
thioethionate (7)

Conclusion: The M. oleifera leaves showed promising antioxidant activities and slightly toxic behavior.

Keywords: Moringa oleifera (Lam.), In vitro antioxidants, TPCs, Oral acute toxicity, Phenolic compounds

(C) 2017 The Authors. Published by Innovare Academic Sciences Pvt Ltd. This is an open access article under the CC BY license (http://creativecommons.org/licenses/by/4.0/) DOI: http://dx.doi.org/10.22159/ijpps.2017v9i5.17834

\section{INTRODUCTION}

Moringa oleifera Lam. (Moringaceae) is an important plant, widely spread in different regions around the world including tropical and subtropical zones [1]. M. oleifera is famous by its nutritional values and numerous medicinal benefits. Moreover, from the nutritional values point of view it was reported that the plant contains vital nutrients i.e., amino acids, some minerals, protein, vitamins, and $\beta$ carotene [1-3]. In traditional and folk medicine, all parts of the plant were used in the treatment of many diseases and health disorders $[4,5]$. Furthermore, different parts of M. oleifera are reported to possess wide range of biological activities i.e., antioxidant [6-8], antitumor [9], antibacterial [8, 10], and hepatoprotective [11, 12]. From phytochemistry point of view, the previous phytochemical investigations were carried on various parts of $M$. oleifera revealed the isolation of different classes of secondary metabolites i.e., polysaccharide [13], flavonol glycosides [14], sterols and terpenes [15], phenolic acids [16], and flavonol aglycones [17]. Therefore, the current study was undertaken to estimate the total phenolic contents (TPCs), in vitro antioxidant of different solvent extracts of M. oleifera leaves, oral acute toxicity and $\mathrm{LD}_{50}$ determination of the $85 \%$ methanolic extract as well as the chromatographic isolation and identification of the most promising extract.

\section{MATERIALS AND METHODS}

Equipments and chemicals

The NMR spectra were recorded at 500 and $125 \mathrm{MHz}$ for $\left({ }^{1} \mathrm{H}\right)$ and $\left({ }^{13} \mathrm{C}\right)$ respectively, on a Varian Mercury, JEOL GLM spectrometers relative to TMS in DMSO- $\mathrm{d}_{6}, \delta$ values are reported in ppm. UV spectra of the extracts and samples were recorded, separately, in $\mathrm{MeOH}$ using different diagnostic UV shift reagents using a Shimadzu UV 240 spectrophotometer. Melting points were achieved using a MeltApparatus (SMDP3 Stuart Scientific UK). The absorbance measurements for antioxidant activity assay were recorded using the UV-Vis spectrophotometer Spectronic 601 (Milton Roy, USA). Sephadex LH-20 (Pharmacia, Uppsala, Sweden), microcrystalline cellulose (Merck, Darmstadt, Germany), polyamide 6S (Riedel-de Haën AG, Seelze, Germany), and silica gel powder (G 70-230 mesh, Merck) were used for column chromatography (CC). Whatman No. 1 sheets were used for paper chromatography.

Aluminum chloride, Ferric chloride, Ascorbic acid, Gallic acid, Quercetin and Ammonium molybdate were purchased from (merck chemical co.), 2,2'-diphenyl-1-picraylhydrazyl (DPPH) free radical and Folin-Ciocalteu's reagent (FCR) was purchased from (SigmaAldrich Co.), Sugar authentic samples (Merck, Germany), all solvents and acids [Methanol, Petroleum ether, Ethyl acetate, Chloroform, $n$ butanol, Acetic acid, Sulphuric acid, Pyridine- $\mathrm{d}_{5}$, Aniline phthalate, and Dimethyl sulphoxide (DMSO)] were purchased from [SigmaAldrich Co.). This work was being done at Medicinal Chemistry Department, Theodor Bilharz Research Institute (TBRI).

\section{Plant materials}

The fresh leaves of Moringa oleifera Lam. (Moringaceae) were collected from El-Sharqya, Egypt during June 2015. The plant was kindly identified and authenticated by Prof. Dr. Wafaa M. Amer, Professor of Plant Taxonomy, Faculty of Science, Cairo University, 
Giza, Egypt. Voucher specimens (given number Mo 1) will be kept in the Medicinal Chemistry Department, Theodor Bilharz Research Institute (TBRI). The plant material undergoes air-drying in shade place at room temperature and then powdered by the electric mill and kept in tightly closed container in dark then, subjected to the extraction process.

\section{Extraction, fractionation and isolation}

The air-dried powdered leaves of $M$. oleifera $\mathrm{L}$. $(1.7 \mathrm{~kg})$ were extracted on cold using aqueous methanol (85\%). The crude $85 \%$ methanolic extract was concentrated via rotatory evaporator to afford (464 g), defatted using petroleum ether $\left(60-80{ }^{\circ} \mathrm{C}\right)$, and then the residue was dissolved in distilled water and successively extracted with organic solvents including; methylene chloride, ethyl acetate, and $n$-butanol, to obtain petroleum ether $(11 \mathrm{~g})$, methylene chloride (25 g), ethyl acetate (10 g), $n$-butanol (146 g), and water (250 g) extracts. The $n$-butanol extract was submitted to column chromatography $(120 \times 6 \mathrm{~cm}, 300 \mathrm{~g})$ packed with polyamide column as stationary phase. Elution started with $\mathrm{MeOH} / \mathrm{H}_{2} \mathrm{O}$ gradient, then fractions of $150 \mathrm{ml}$ were collected, concentrated and examined by paper chromatography using solvent systems $\left(n-\mathrm{BuOH}\right.$ : $\mathrm{AcOH}: \mathrm{H}_{2} \mathrm{O}$; 4:1:5; v/v/v; upper phase; PC; $\left.S_{1}\right)$ and $\mathrm{AcOH}: \mathrm{H}_{2} \mathrm{O}$ (15:85; v/v; PC; $S_{2}$ ). Four major fractions (I-IV) with phenolic nature were eluted within different polarities from the polyamide column using aqueous methanol $\left(\mathrm{MeOH} / \mathrm{H}_{2} \mathrm{O}\right)$ as elution system $(5: 95 ; 10: 90$; $20: 80$ and $30: 70 \mathrm{v} / \mathrm{v}$ ), respectively for the fractions I, II, III and IV. Fraction (I) was purified on Sephadex LH-20 to give compound 1. Fraction (II) was re-chromatographed on Sephadex LH-20 to give compounds 2 and 3 . Fraction (III) was undergoing further repeated purification on Sephadex LH-20 to give compounds 4 and 5. Finally, fraction (IV) was subjected to extra purification on Sephadex LH-20 to give compounds 6 and 7. The isolated compounds were identified on the basis of their ${ }^{1} \mathrm{H}$ and ${ }^{13} \mathrm{C}$-NMR spectra and chemical methods.

\section{Acid hydrolysis for compounds 1, 3 and 4}

Complete acid hydrolysis for the glycoside compounds was carried out $(2 \mathrm{mg}$ ) each was refluxed for $4 \mathrm{~h}$ in $10 \mathrm{ml}$ of $2 \mathrm{~N} \mathrm{HCl}$. The hydrolysate aglycone was extracted with diethyl ether, and then evaporated to dryness, then was identified by paper chromatography. The sugars in the mother liquor layer were neutralised and were subjected to comparative-paper chromatography (Co-PC) with authentic samples using solvent system [n-BuOH:AcOH: $\mathrm{H}_{2} \mathrm{O}, 4: 1: 5$, upper layer] by using aniline phthalate spray as the detection reagent.

\section{Total phenolic contents $\left(\mathrm{TPC}_{\mathrm{s}}\right)$}

The total phenolic contents of different solvent extracts of M. oleifera leaves were estimated using Folin-Ciocalteu's reagent according to the reported procedures [18].

\section{In vitro antioxidant activity}

\section{Reducing power antioxidant activity (RPAA) assay}

The reducing power antioxidant activity of the different extracts was estimated according to the reported procedure $[18,19]$.

\section{Phosphomolybdenum assay}

The total antioxidant capacity (TAC) was determined according to phosphomolybdenum assay $[18,20,21]$.

\section{Dot-blot and DPPH staining assay}

The antioxidant by dot-blot and DPPH staining was qualitatively estimated according to reported method $[18,22]$.

\section{Oral acute toxicity study and determination of median lethal dose $\mathrm{LD}_{50}$}

This study was designed to assess the acute oral toxicity produced when the test material, M. oleifera and M. peregrina $85 \%$ methanol extracts, was administered by oral gavage to mice. The neat test material was administered by oral gavage at different dose levels $(250,500,1000,2000,3000$ and $5000 \mathrm{mg} / \mathrm{kg}$ body weight) to a total of 6 healthy mice for each concentration. Adult male albino mice weighing $(25-30 \mathrm{~g})$ were used for the study. Animals were procured from Schistosome Biological Supply Centre (SBSC) at theodor
Bilharz Research Institute (TBRI), Imbaba, Giza, Egypt. All the animals were acclimatized for a week under standard husbandry conditions. The animals were housed in polypropylene cages $(45 \times 24 \times 15 \mathrm{~cm})$, maintained under the temperature of $25 \pm 2{ }^{\circ} \mathrm{C}$ and $12 \mathrm{~h}$ light $/ 12 \mathrm{~h}$ dark condition. The animals had free access to standard pellet diet and water ad libitum was available to the animals throughout the experimental period. The standard pellet diet contained $24 \%$ protein, $4 \%$ fat, $4.5 \%$ fibre and $2 \%$ vitamin. For determination of $\mathrm{LD}_{50} M$. oleifera and M. peregrina methanol extracts were tested on uninfected mice to determine the threshold toxic dose. $\mathrm{LD}_{50}$ of each extract was thus determined using the method described by Wilbrandt (1952). Groups of 6 mice, weighing 20-25 g each, were used. One group was given orally the respective amount of DMSO and left as a control. Different doses expressed by $\mathrm{mg} / \mathrm{kg}$ (b. wt.) of each extract were administered. The toxic symptoms and mortality rate in each group were recorded after $24 \mathrm{~h}$ and $14 \mathrm{~d}$. $\mathrm{LD}_{50}$ of each extract was calculated according to the formula [23]:

$$
\mathrm{LD}_{50}=\mathrm{Dm}-\Sigma(\mathrm{Zxd}) / \mathrm{n}
$$

Where,

Dm is the minimum dose which kills all animals in the group;

$\mathrm{Z}$ is the mean of dead animals in two successive groups;

$\mathrm{d}$ is the constant factor between two successive groups;

$\mathrm{n}$ is the number of animals of each group; and

$\Sigma$ is the sum of (Zxd).

\section{RESULTS AND DISCUSSION}

\section{Total phenolic contents (TPC)}

The TPCs values of the tested extracts of $M$. oleifera leaves were varied from 309.52 to $43.28 \mathrm{mg}$ gallic acid equivalent/g dry extract, and were in the order of $[n-\mathrm{BuOH}(309.52)>$ EtOAc $(207.78)>85 \%$ $\mathrm{MeOH}(164.49)>\mathrm{H}_{2} \mathrm{O}(106.04)>\mathrm{CH}_{2} \mathrm{Cl}_{2}(64.93)>$ pet. ether (43.28)] mg gallic acid equivalent/g dry extract. The $n$-BuOH and EtOAc extracts were found to have high TPCs, water extract showed moderate TPCs value, while $\mathrm{CH}_{2} \mathrm{Cl}_{2}$ and pet. ether extracts were found to have low TPCs; compared to $85 \% \mathrm{MeOH}$ extract of $M$. oleifera flowers of TPCs 127.70 and $85 \% \mathrm{MeOH}$ extract of $M$. peregrina leaves of TPCs $142.85 \mathrm{mg}$ gallic acid equivalent/g dry extract (table 1). Reviewing the literature, revealed that the aqueous extract of fresh fruits of $M$. oleifera growing in India showed TPCs of $125 \mathrm{mg}$ gallic acid equivalent/g dry extract [24]. Kalpna et al., (2011) reported that the different solvent extracts of M. oleifera growing in India exhibited TCPs of 1.05, 7.34, 29.94, and $16.87 \mathrm{mg}$ gallic acid equivalent/g dry extract, respectively for $n$-hexane, chloroform, acetone and methanol extracts [25]. Moreover, the TPCs of the water extract of mature and tender leaf M. oleifera growing in India were, 45.81 and $36.02 \mathrm{mg}$ gallic acid equivalent/g dry extract, respectively [26]. On the other hand, the TPCs of the $100 \% \mathrm{MeOH}$ and water extracts of $M$. oleifera leaves growing in Egypt were found to be 63.53 and $37.6 \mathrm{mg}$ gallic acid equivalent/g dry extract, respectively [27].

\section{In vitro antioxidant activity}

Based on the previous reports, the polyphenolic compounds as a characteristic class of plant secondary metabolites are mainly responsible for the antioxidant potential of the tested extracts due to their high abilities as free radical scavengers [28]. The synergistic effect (Co-activity) play a vital role during the estimation of antioxidant activity of plant extracts as a complex mixture containing a large number of combined compounds. These compounds may be reinforcing each other leading to raising their antioxidant potential and vice versa $[20,29,30]$.

\section{Reducing power antioxidant activity (RPAA)}

In the current study, the in vitro antioxidant activity of different solvent extracts $M$. oleifera was evaluated via three antioxidant assays. The reducing power antioxidant activity (expressed in optical density; OD values) were in the order of $[n-\mathrm{BuOH}(0.434)>$ EtOAc $(0.402)>85 \% \mathrm{MeOH}(0.395)>\mathrm{H}_{2} \mathrm{O}(0.149)>\mathrm{CH}_{2} \mathrm{Cl}_{2}(0.143)>$ 
pet. ether (0.124)], compared to ascorbic acid as a positive control (0.915), $85 \% \mathrm{MeOH}$ of $M$. oleifera flowers and $85 \% \mathrm{MeOH}$ of $M$. peregrina leaves with OD values of $0.915,0.174$ and 0.384 , respectively (fig. 1). The literature survey denoted that the RPAA of $100 \% \mathrm{MeOH}$ and water extracts of $M$. oleifera leaves were 271.12 and $134.30 \mathrm{mg}$ equivalent to ascorbic acid/g dry extract [27]. Moreover, the RPAA depends on ability of the tested samples in the reduction of the $\mathrm{Fe}^{3+} /$ ferricyanide complex to $\mathrm{Fe}^{2+} /$ ferricyanide complex, which can be examined by reading the absorbance (OD value) at $700 \mathrm{~nm}[18]$.

Table 1: Total phenolic contents (TPCs) of different solvent extracts of $M$. oleifera leaves, $85 \%$ MeOH extract of $M$. oleifera flowers and $85 \% \mathrm{MeOH}$ extract of $M$. peregrina leaves

\begin{tabular}{ll}
\hline Sample & Total phenolic (mg gallic acid equivalent/g dry extract) $\mathbf{1}^{ \pm}$SD \\
\hline 85\% MeOH, M. oleifera leaves & $164.49 \pm 2.10$ \\
Pet. Ether & $43.28 \pm 1.95$ \\
$\mathrm{CH}_{2} \mathrm{Cl}_{2}$ & $64.93 \pm 1.49$ \\
$\mathrm{EtOAc}$ & $207.78 \pm 1.54$ \\
$n-\mathrm{BuOH}$ & $309.52 \pm 1.25$ \\
$\mathrm{H}_{2} \mathrm{O}$ & $106.04 \pm 1.33$ \\
$85 \% \mathrm{MeOH}$, . oleifera flowers & $127.70 \pm 2.12$ \\
$85 \% \mathrm{MeOH}$. peregrina leaves & $142.85 \pm 1.65$ \\
\hline
\end{tabular}

All measurement were carried out in triplicate, and values were expressed as mean \pm standard deviation (SD) ( $n=3)$. ${ }^{1}$ Total phenolic contents were expressed as mg gallic acid equivalent/g extract.

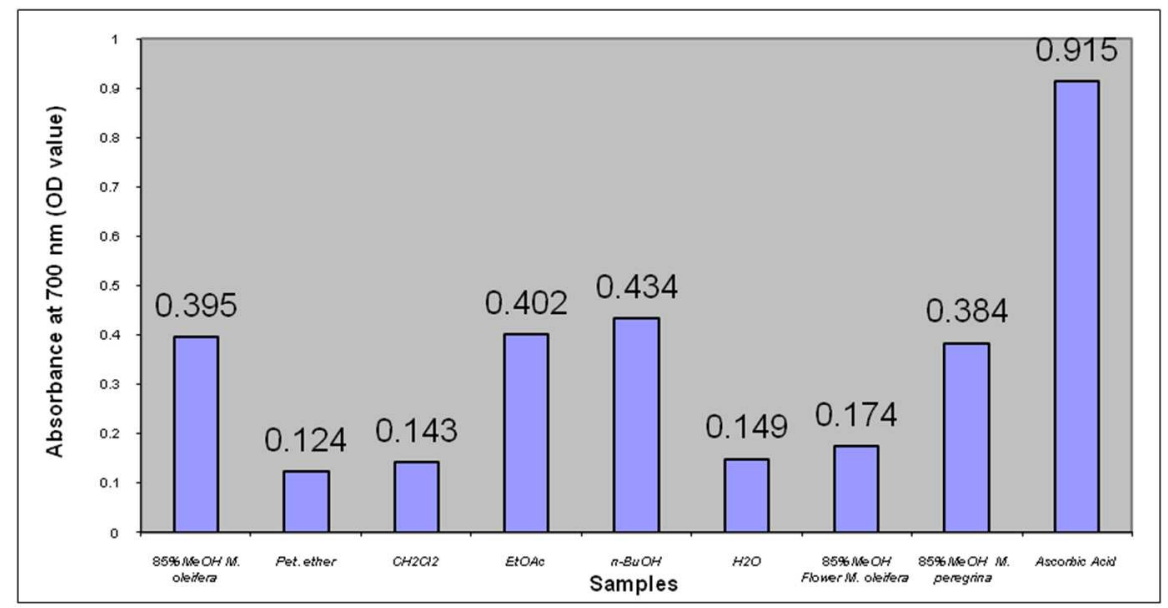

Fig. 1: Reducing power activity of different solvent extracts of $M$. oleifera leaves, $85 \% \mathrm{MeOH}$ extract of $M$. oleifera flowers and $85 \%$ MeOH extract of M. peregrina leaves at concentration $200 \mu \mathrm{g} / \mathrm{ml}$ in comparison to ascorbic acid as positive control, the measurement were carried out in triplicate $(n=3)$

\section{Total antioxidant capacity (TAC)}

In this assay, the mode of action is based on the reduction of $\mathrm{Mo}^{\mathrm{VI}}$ to $\mathrm{Mo}^{\mathrm{V}}$ leading to a green phosphate $/ \mathrm{Mo}^{\mathrm{V}}$ complex can be monitored at $765 \mathrm{~nm}[20,31]$. The results in (table 2) revealed that the high TAC value was recorded with $n-\mathrm{BuOH}$ of $316.43 \mathrm{mg}$ ascorbic acid equivalent/g dry extract, followed by $85 \% \mathrm{MeOH}$, EtOAc and $\mathrm{H}_{2} \mathrm{O}$ with TAC values of $203.35,181.56$ and $86.70 \mathrm{mg}$ ascorbic acid equivalent/g dry extract, respectively. On the other hand, the low TAC values were recorded with $\mathrm{CH}_{2} \mathrm{Cl}_{2}$ and pet. either with TAC values of 76.62 and $50.83 \mathrm{mg}$ ascorbic acid equivalent/g dry extract, respectively. These above mentioned TAC values were compared with those of $85 \% \mathrm{MeOH}$ (M. oleifera flowers) and $85 \% \mathrm{MeOH}(M$. peregrina leaves) 98.30 and $193.25 \mathrm{mg}$ ascorbic acid equivalent/g dry extract, respectively. It was reported that; the TAC values of the $100 \% \mathrm{MeOH}$ and $\mathrm{H}_{2} \mathrm{O}$ extracts of $M$. oleifera leaves were 324.44 and $153.33 \mathrm{mg}$ ascorbic acid equivalent/g dry extract, which in some agreement with our results [27].

Furthermore, there are many previous reports indicated the presence of a highly positive correlation between the antioxidant activities and total phenolic contents of the tested extracts/fractions [18, 32, 33].

Table 2: Total antioxidant capacity (TAC) of different solvent extracts of $M$. oleifera leaves, $85 \%$ MeOH extract of $M$. oleifera flowers and 85\% MeOH extract of $M$. peregrina leaves

\begin{tabular}{ll}
\hline Sample & Total antioxidant capacity (mg ascorbic acid equivalent/g dry extract) $\mathbf{1}^{ \pm \text {SD }}$ \\
\hline $85 \% \mathrm{MeOH}$ & $203.35 \pm 1.50$ \\
Pet. Ether & $50.83 \pm 1.44$ \\
$\mathrm{CH}_{2} \mathrm{Cl}_{2}$ & $76.62 \pm 1.25$ \\
$\mathrm{EtOAc}$ & $181.56 \pm 1.15$ \\
$n-\mathrm{BuOH}$ & $316.43 \pm 1.20$ \\
$\mathrm{H}_{2} \mathrm{O}$ & $86.70 \pm 1.40$ \\
$85 \% \mathrm{MeOH}$ M. oleifera flowers & $98.30 \pm 1.56$ \\
$85 \% \mathrm{MeOH}$ M. peregrina leaves & $193.25 \pm 1.65$ \\
\hline
\end{tabular}

All measurement were carried out in triplicate, and values were expressed as mean \pm standard deviation ( $n=3$ ), ${ }^{1}$ Total antioxidant capacity was expressed as mg ascorbic acid equivalent/g dry extract. 


\section{Dot-blot and DPPH staining antioxidant activity}

The current assay depends on the ability of the antioxidant compounds to act as strong free radical scavengers in a visible model. During the reaction the strong antioxidant agent able to mask the 2, 2'-diphenyl-1picrylhydrazyl radical (DPPH) displayed by a purple background, then followed by a formation of a wide white zone. The big zone diameter and brightness is a good indicator for the strong antioxidant activity and the tested sample in such case acts as a good free radical scavenger [34]. Accordingly, as shown in (fig. 2) the $n-\mathrm{BuOH}, 85 \% \mathrm{MeOH}$ and EtOAc extracts of M. oleifera leaves are good free radical scavengers compared to two well-known standards quercetin and ascorbic acid. Moreover, the $85 \% \mathrm{MeOH}$ of $M$. oleifera flowers and $85 \% \mathrm{MeOH}$ of $M$. peregrina leaves are considered promising free radical scavengers. The obtained results are in full agreement with the previous studies were done on other plant species [18, 34-37].

$85 \% \mathrm{MeOH}$
Pet. ether
$\mathrm{CH}_{2} \mathrm{Cl}_{2}$
EtOAc
$n$-BuOH
$\mathrm{H}_{2} \mathrm{O}$
$85 \% \mathrm{MeOH}$, M. oleifera flowers
$85 \% \mathrm{MeOH}$, M. peregrina
Quercetin
Ascorbic acid

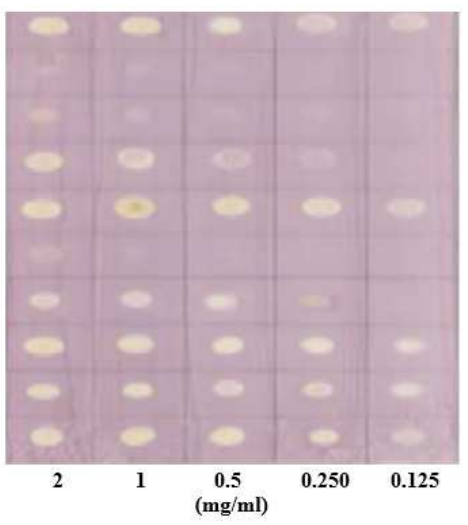

Fig. 2: Dot-blot qualitative antioxidant assay of different fractions of $\mathrm{M}$. oleifera leaves in comparison with $85 \% \mathrm{MeOH}$ of $\mathrm{M}$. oleifera flowers and $85 \% \mathrm{MeOH}$ of $\mathrm{M}$. peregrina leaves on silica sheet stained with DPPH• solution in methanol against quercetin and ascorbic acid as standards
Oral acute toxicity study and determination of median lethal dose $\mathrm{LD}_{50}$

\section{General sign and behavioral analysis}

The toxicological results (tables 3,4 ) revealed that there is no any effect was showed for the two tested extracts on the appearance and the general behavioural pattern of mice. No toxic symptoms were observed in any animals, which lived up to $14 \mathrm{~d}$ after the administration of each extract at different doses $(100,250,500$, 1000 and $2000 \mathrm{mg} / \mathrm{kg}$ body weight) in animals that treated with 85\% methanol extracts of $M$. oleifera and M. peregrina.

The behavioral patterns of animals were observed first $24 \mathrm{~h}$ and followed by $14 \mathrm{~h}$ after the administration and the animals in both vehicle-treated and M. peregrina extract-treated groups were normal and did not display significant changes in behavior, skin effects, breathing, impairment in food intake and water consumption and hair loss up to $5000 \mathrm{mg} / \mathrm{kg}$ body weight. Concerning of animal that treated with $5000 \mathrm{mg} / \mathrm{kg}$ body weight of $M$. oleifera $85 \%$ methanol extract some changes in the behavioural patterns of animals were observed like a decrease in impairment in food intake, weight loss and an increase in the activity. A literature survey revealed that many previous toxicological studies were carried out on different Moringa species especially M. oleifera [38-40].

The $\mathrm{LD}_{50}$ of the aqueous methanol extract of $M$. oleifera leaves was found to be greater than $2000 \mathrm{mg} / \mathrm{kg}$ in female wistar albino rats [41], while in the current study the $\mathrm{LD}_{50}$ of the methanolic extract was $3458.3 \mathrm{mg} / \mathrm{kg}$ in male wistar albino mice. Kasolo et al., (2011) reported that, the $L D_{50}$ values of the ethanolic and aqueous extracts of M. oleifera roots growing in Uganda were $17.8 \mathrm{~g} / \mathrm{kg}$ and $15.9 \mathrm{~g} / \mathrm{kg}$, respectively [42]. In another toxicological study done on the ethanolic and aqueous extracts of M. oleifera leaves growing in Uganda, the ethanolic extract showed no any toxicity while the aqueous extract showed mild toxicity in the treated animals during the oral administration [43]. Moreover, the acute oral toxicity study of the methanolic extract of $M$. oleifera bark revealed that; the $\mathrm{LD}_{50}$ was found to be $>2000-5000 \mathrm{mg} / \mathrm{kg} \mathrm{b}$. wt [44].

Table 3: Lethal dose $\mathrm{LD}_{50}$ of $85 \%$ methanol extract of $M$. oleifera leaves

\begin{tabular}{|c|c|c|c|c|c|}
\hline Dose (mg/kg b. wt.) & Number of mice & Number of dead mice & $\mathbf{Z}$ & D & (Z)x(d) \\
\hline 250 & 6 & 0 & 0 & 250 & 0 \\
\hline 500 & 6 & 0 & 0 & 375 & 0 \\
\hline 1000 & 6 & 0 & 0 & 750 & 0 \\
\hline 2000 & 6 & 1 & 0.5 & 1500 & 750 \\
\hline 3000 & 6 & 1 & 1 & 2500 & 2500 \\
\hline 5000 & 6 & 2 & 1.5 & 4000 & 6000 \\
\hline
\end{tabular}

$\mathrm{LD}_{50}=5000-(9250 / 6)=5000-1541.7=3458.3 \mathrm{mg} / \mathrm{kg}$

Table 4: Lethal dose $\mathrm{LD}_{50}$ of $85 \%$ methanol extract of $M$. peregrina leaves

\begin{tabular}{|c|c|c|c|c|c|}
\hline Dose (mg/kg b. wt.) & Number of mice & Number of dead mice & $\mathbf{Z}$ & $\mathbf{d}$ & $(Z) \times(d)$ \\
\hline 250 & 6 & 0 & 0 & 250 & 0 \\
\hline 500 & 6 & 0 & 0 & 375 & 0 \\
\hline 1000 & 6 & 0 & 0 & 750 & 0 \\
\hline 2000 & 6 & 0 & 0 & 1500 & 0 \\
\hline 3000 & 6 & 1 & 0.5 & 2500 & 1250 \\
\hline 5000 & 6 & 1 & 1 & 4000 & 4000 \\
\hline
\end{tabular}

$\mathrm{LD}_{50}=5000-(5250 / 6)=5000-875=4125 \mathrm{mg} / \mathrm{kg}$, the two extracts under investigation could be classified as slightly toxic in the scale of Hodge and Sterner.

\section{Identification of the isolated compounds}

Compound 1 was obtained as pale brown powder, m. p. $233{ }^{\circ} \mathrm{C}, \mathrm{R}_{\mathrm{f}} ;$ $0.86\left(S_{2}\right)$. It showed yellow colour under UV light. ${ }^{1} \mathrm{H}-\mathrm{NMR}$ spectral data $\left(500 \mathrm{MHz}\right.$, DMSO- $\left.d_{6}\right)$ revealed to the presence of four aromatic signals characteristic for cinnamoeyl moiety at $\delta 7.32(2 \mathrm{H}, b r d, \mathrm{H}-2$, $\mathrm{H}-6)$ and $7.12(2 \mathrm{H}, \mathrm{brd}, \mathrm{H}-3, \mathrm{H}-5)$, two methine protons at $\delta 6.91(1 \mathrm{H}$, brd, H-7), $5.32(1 \mathrm{H}, d, J=14.35 \mathrm{~Hz}, \mathrm{H}-8)$, two anomeric protons for glucosyl moiety at $\delta 4.49\left(1 \mathrm{H}, b r s, \mathrm{H}-1^{\prime}\right)$ and apiofuranosyl moiety at $\delta 4.91\left(1 \mathrm{H}, \mathrm{brd}, \mathrm{H}-1^{\prime \prime}\right)$, finally $3.2-3.55(\mathrm{~m}$, remaining sugars- protons). ${ }^{13} \mathrm{C}-\mathrm{NMR}$ spectral data $\left(125 \mathrm{MHz}\right.$, DMSO- $d_{6}$ ) revealed to the presence of twenty carbon resonances; including six aromatic signals characteristic for cinnamoeyl moiety appeared at $\delta 130.63$ (C-1), 129.86 (C-2), 116.90 (C-3), 155.96 (C-4), 116.90 (C-5), and $129.86(\mathrm{C}-6)$, two methine carbons at $\delta 128.69(\mathrm{C}-7), 124.88(\mathrm{C}-8)$ and 178.02 (C-9). Six carbon signals for glucosyl moiety including anomeric carbon resonance at $\delta 98.82\left(\mathrm{C}^{\prime} 1^{\prime}\right), 81.53$ (C-2'), 82.26 (C3'), 69.93 (C-4'), 73.24 (C-5'), 61.52 (C-6'). Five carbon signals for apiofuranosyl moiety including anomeric carbon resonance at $\delta$ 
104.73 (C-1"), 72.03 (C-2"), 81.53 (C-3"), 73.24 (C-4") and 63.48 (C$5^{\prime)}$ (table 5). Furthermore, acid hydrolysis of the compound afforded glucose and apiose sugar in the aqueous phase which was confirmed by Co-thin layer chromatography (Co-TLC) with authentic sugar sample. All protons and carbons resonances were in agreement with the reported data [45], therefore, compound 1 was identified as cis-pcoumaric acid 4-O-(2'-O- $\beta$-D-apiofuranosyl)- $\beta$-D-glucopyranoside.

Compound 2 was obtained as a white powder, m. p. $200-202{ }^{\circ} \mathrm{C}, \mathrm{R}_{\mathrm{f}}, 0.77$ $\left(S_{2}\right)$. It gave effervescence with sodium bicarbonate indicating its acidic nature; also it showed deep blue spot upon paper chromatography under long UV wavelength. Based on the Co-PC with the authentic sample, compound 2 was identified as chlorogenic acid [46].

Compound 3 was isolated as pale yellow fine crystals, m. p.170-172 ${ }^{\circ} \mathrm{C}, \mathrm{R}_{\mathrm{f}}, 0.40\left(S_{2}\right)$. It showed a characteristic spot with fluorescent violet colour under UV light. ${ }^{1} \mathrm{H}-\mathrm{NMR}$ spectral data $\left(500 \mathrm{MHz}\right.$, DMSO- $d_{6}$ ) revealed to the presence of a set of protons including two resonances in the aromatic region (AB system); at $\delta 7.02 \mathrm{ppm}(2 \mathrm{H}, d, J=7.65 \mathrm{~Hz}, \mathrm{H}-$ 2,6), $7.24 \mathrm{ppm}(2 \mathrm{H}, d, J=7.65 \mathrm{~Hz}, \mathrm{H}-3,5)$, and one characteristic signal for benzylic methylene group at $3.91 \mathrm{ppm}(2 \mathrm{H}, s, \mathrm{H}-7)$, anomeric proton at $\delta 5.33 \mathrm{ppm}\left(1 \mathrm{H}, b r s, \mathrm{H}-1^{\prime}\right)$, signal for methyl group of sugar moitey at $1.05 \mathrm{ppm}\left(3 \mathrm{H}, d, J=5.75 \mathrm{~Hz}, \mathrm{CH}_{3}-\mathrm{Rha}\right)$, and $3.58-4.76 \mathrm{ppm}$ (4H, H-2', $3^{\prime}, 4^{\prime}, 5^{\prime}$; rest of sugar protons). ${ }^{13} \mathrm{C}-\mathrm{NMR}$ spectral data $(125$ $\mathrm{MHz}$, DMSO- $\left.d_{6}\right)$ revealed to the presence of twelve carbon resonances were assigned to six aromatic carbons at $\delta 155.99$ (C-1), 117.43 (C2,6), 129.86 (C-3,5), 131.0 (C-4), and one methylen carbon at $\delta 22.12$ (C-7), characteristic carbon signal for nitril moiety at $\delta 124.91$ (C-8), anomeric carbon for the rahmonosyl moiety at $\delta 98.90$ (C-1'), the remaining carbons of sugar moieties were appeared at $\delta 70.68$ (C-2'), $70.04\left(\mathrm{C}^{-} 3^{\prime}\right), 70.96\left(\mathrm{C}-4^{\prime}\right), 65.80\left(\mathrm{C}^{\prime} 5^{\prime}\right)$, and the most upfield methyl carbon at $\delta 18.41 \mathrm{ppm}\left(\mathrm{C}-6^{\prime}, \mathrm{CH}_{3}-\mathrm{Rha}\right)$ (table 5). Otherwise, the complete acid hydrolysis of the compound revealed L-rhamnose in the aqueous phase which was detected by Co-thin layer chromatography (Co-TLC) with authentic sugar. All protons and carbons shifts were in full agreement with the literature $[47,48]$, therefore, compound 3 was identified as $4-[(\alpha-L-r h a m n o s y l o x y)$ benzyl] nitrile (niazirin).

Compound 4 was obtained as pale brown fine crystals, m. p. $287^{\circ} \mathrm{C}$, $\mathrm{R}_{\mathrm{f}}$; $0.76\left(S_{2}\right)$. It showed a blue colour under long UV wave length. ${ }^{1} \mathrm{H}-$ NMR spectral data $\left(500 \mathrm{MHz}\right.$, DMSO- $d_{6}$ ) revealed the presence of three aromatic protons resonances corresponding to cinnamoeyl moiety [(E)-caffeoyl moiety] at $\delta 7.73\left(1 \mathrm{H}, b r s, \mathrm{H}-2^{\prime}\right), 7.12\left(1 \mathrm{H}, b r d, \mathrm{H}^{-} 5^{\prime}\right), 7.20$ $\left(1 \mathrm{H}, b r d, \mathrm{H}-6^{\prime}\right)$, two protons at $\delta 7.87\left(1 \mathrm{H}, d, J=15.5 \mathrm{~Hz}, \mathrm{H}-7^{\prime}\right)$ and 6.27 $\left(1 \mathrm{H}, d, J=15.5 \mathrm{~Hz}, \mathrm{H}-8^{\prime}\right)$, another set of three aromatic protons at $\delta 6.91$ $(1 \mathrm{H}$, brs, $\mathrm{H}-2), 6.65(1 \mathrm{H}$, brd, $\mathrm{H}-5)$, and $6.51(1 \mathrm{H}, b r d, \mathrm{H}-6)$, the appearance of three aliphatic protons at $\delta 2.79(2 \mathrm{H}, t, \mathrm{H}-7), 3.89(1 \mathrm{H}$, $m, \mathrm{H}-8 \mathrm{a}), 4.03(1 \mathrm{H}, m, \mathrm{H}-8 \mathrm{~b})$ is characteristic for the presence of $3,4-$ dihydroxy phenylethanoid moiety. In, addition, three characteristic signals for three anomeric protons at $\delta 4.54(1 \mathrm{H}, b r s, \mathrm{H}-1 \mathrm{l}), 5.61(1 \mathrm{H}$, $\left.d, J=7.65, \mathrm{~Hz}, \mathrm{H}-1{ }^{\prime \prime \prime}\right)$, and $5.28\left(1 \mathrm{H}, b r s, \mathrm{H}-1^{\prime \prime \prime \prime)}\right.$. The remaining sugars protons appeared at $\delta 3.50-3.79 \mathrm{ppm}$, two methyl protons at $\delta 0.82$ ( $3 \mathrm{H}, d, J=5.75, \mathrm{~Hz}$, Rha- $\left.6^{\prime \prime \prime}\right)$, and 1.26 (3H, brd, Rha- $6^{\prime \prime \prime \prime)}$. Moreover, the complete acid hydrolysis of the compound afforded D-glucose and Lrhamnose in the aqueous phase which was detected by Co-thin layer chromatography (Co-TLC) with authentic sugar markers. All protons resonances were in agreement with the reported data [49], therefore, compound 4 was identified as 3,4-dihydroxy- $\beta$-phenylethoxy- $O-\alpha-\mathrm{L}-$ rhamnopyranosyl -(l-2)- $\alpha$-L-rhamnopyranosyl- $(1 \rightarrow 3)-4-0$-caffeoyl- $\beta$ D-glucopyranoside (phlinoside C).

Compound 5 was obtained as a white powder; m. p. $250-252^{\circ} \mathrm{C}, \mathrm{R}_{\mathrm{f}}$ $0.75\left(S_{1}\right)$ and $0.55\left(S_{2}\right)$. It gave a dark violet spot under long UV wavelength; also it showed effervescence with sodium bicarbonate indicating its acidic nature [46]. According to the Co-PC with the authentic sample, compound 5 was identified as gallic acid.

Compound 6 was obtained as a dark yellow powder; m. p. 232-234 ${ }^{\circ} \mathrm{C}, \mathrm{R}_{\mathrm{f}} ; 0.03\left(S_{2}\right)$. It gave a dark yellow spot under long UV light not affected with $\mathrm{AlCl}_{3}$. Based on the Co-PC with the authentic sample, compound 6 was identified as taxifolin [46].

Compound 7 was isolated as pale brown fine needles, m. p. 60-62 ${ }^{\circ} \mathrm{C}, \mathrm{R}_{\mathrm{f}} ; 0.82\left(S_{2}\right)$. It showed a blue color under long UV light. ${ }^{1} \mathrm{H}-\mathrm{NMR}$ spectral data $\left(500 \mathrm{MHz}, \mathrm{DMSO}-d_{6}\right)$ revealed the presence of five aromatic signals characteristic for mono-substituted phenyl ring at $\delta$ $7.48(1 \mathrm{H}, m, \mathrm{H}-2), 7.67(1 \mathrm{H}, m, \mathrm{H}-3), 7.48(1 \mathrm{H}, m, \mathrm{H}-4), 7.67(1 \mathrm{H}, m$, $\mathrm{H}-5)$, and $7.48(1 \mathrm{H}, m, \mathrm{H}-6)$. Two methylene groups appeared at $\delta$ $4.09(2 \mathrm{H}, b r d, \mathrm{H}-7)$, and $3.13(2 \mathrm{H}, b r d, \mathrm{H}-9)$, and characteristic signal for amino proton at $\delta 5.66(1 \mathrm{H}, b r s, \mathrm{~N}-\mathrm{H})$. All protons resonances were in agreement with the reported data [50], therefore, compound 7 was identified as benzyl-carbamothioethionate.

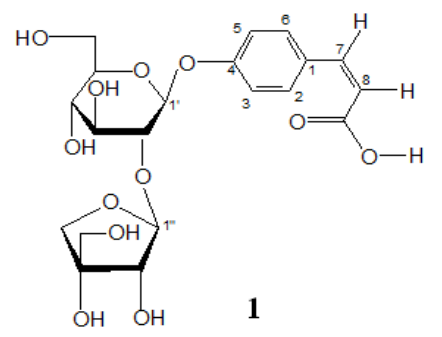<smiles>O=C(/C=C/c1ccc(O)c(O)c1)OC1CC(O)(C(=O)O)C[C@H](O)[C@H]1O</smiles><smiles>C[C@@H]1O[C@H](Oc2ccc(C[Hg])cc2)[C@H](O)[C@@H](O)[C@H]1O</smiles>

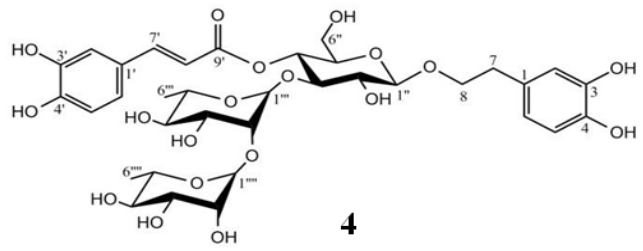<smiles>COc1cc(O)c(O)c(O)c1</smiles>

5<smiles>O=C1c2c(O)cc(O)cc2O[C@H](c2ccc(O)c(O)c2)[C@@H]1O</smiles><smiles>CCSC(=O)NCc1ccccc1</smiles>

\section{7}

Fig. 3: Chemical structures of the compounds isolated from $M$. oleifera leaves 
Table 5: ${ }^{1} \mathrm{H}$ and ${ }^{13} \mathrm{C}$ NMR spectral data (500/125 MHz-DMSO-d $)$ of compounds 1 and 3

\begin{tabular}{|c|c|c|c|c|}
\hline \multirow[t]{2}{*}{ Position } & \multicolumn{2}{|l|}{ Compound 1} & \multicolumn{2}{|l|}{ Compound 3} \\
\hline & $\delta_{H}$ ppm $^{1}$ and $J$ in $\mathrm{Hz}^{2}$ & $\delta_{c} \mathbf{p p m}$ & $\delta_{H}$ ppm and $J$ in $\mathrm{Hz}$ & $\delta_{C} \mathbf{p p m}$ \\
\hline 1 & - & 130.63 & - & 155.99 \\
\hline 2 & 7.32, brd & 129.86 & $7.02, d, J=7.65$ & 117.43 \\
\hline 3 & 7.12, brd & 116.90 & $7.24, J=7.65$ & 129.86 \\
\hline 4 & - & 155.96 & & 131.0 \\
\hline 5 & 7.12, brd & 116.90 & $7.24, J=7.65$ & 129.86 \\
\hline 6 & 7.32, brd & 129.86 & $7.02, d, J=7.65$ & 117.43 \\
\hline 7 & $6.91, b r d$ & 128.69 & $3.91, s$ & 22.12 \\
\hline 8 & $5.32, d, J=14.35$ & 124.88 & - & 124.91 \\
\hline 9 & - & 178.02 & - & - \\
\hline $1^{\prime}$ & 4.49, brs & 98.82 & 5.33, brs & 98.90 \\
\hline $2^{\prime}$ & - & 81.53 & & 70.68 \\
\hline $3^{\prime}$ & - & 82.26 & & 70.04 \\
\hline $4^{\prime}$ & - & 69.93 & & 70.96 \\
\hline $5^{\prime}$ & - & 73.24 & & 65.80 \\
\hline $6^{\prime}$ & - & 61.52 & $1.05,3 \mathrm{H}, d, J=5.75$ & 18.41 \\
\hline $1 "$ & $4.91, b r d$ & 104.73 & & - \\
\hline $2^{\prime \prime}$ & & 72.03 & & - \\
\hline $3 "$ & & 81.53 & & - \\
\hline $4 "$ & & 73.24 & & - \\
\hline $5^{\prime \prime}$ & & 63.48 & & - \\
\hline Rest sugar protons & $3.2-3.55, m$ & - & $3.58-4.76,4 \mathrm{H}, m$ & - \\
\hline
\end{tabular}

${ }^{1} \delta$ : Chemical shifts in ppm, ${ }^{2} \mathrm{~J}$ : Coupling constant in $\mathrm{Hz}$.

\section{Antioxidant activity of the isolated compounds}

Phenolic antioxidants plant-source has gotten a lot of consideration now for their anticancer activities. Antioxidants organization may, therefore, help to eliminate ROS and accordingly enhance the clinical outcome. It is believed that dietary antioxidants can improve cell protection and help to prevent oxidation harm to cellular ingredients.

The isolated compounds were investigated as free radical scavengers via DPPH method. The results in (table 6) showed that; the $\mathrm{SC}_{50}$ values of the isolated compounds were 8.45, 6.25, 5.75, 4.35 and $10.65 \mu \mathrm{g} / \mathrm{ml}$, respectively for the compounds $1,2,4,5$ and 6 ; compared to $8.25 \mu \mathrm{g} / \mathrm{ml}$ of ascorbic acid as standard, while there is no any activity was recorded with the compounds 3 and 7.

Gallic acid possesses an antioxidant capacity correlated to the three hydroxyl groups and the $\mathrm{OH}$ group at para-position to the carboxylic group is fundamental for its activity [51].

Orthodiphenolic functionalities likewise influenced the structureantioxidant activity relationships of phenolic compounds, including gallic acid and chlorogenic acid; it could well guarantee a relatively total spin density delocalization [52], this leads to these compounds possess higher antioxidant activities than that within a single free-OH group on the ring; thus causes the stability for the formed radical.
Chlorogenic acid (CGA), which is cinnamic acid derivative with biological effects mostly, related to its antioxidant activity, it has a vicinal hydroxyl groups on an aromatic deposit, and it showed antioxidant activities in vitro, which is responsible to scavenge reactive oxygen species (ROS), it can immediately interact with peroxyl radical, scavenging and changing over it into a great less active material with quinonic structure [51, 53], moreover, caffeic acid has a stronger antioxidant activity than that of chlorogenic acid.

It was illustrated, that; the antioxidant property of phenolic compounds increases within the increasing in the number of hydroxyl groups connected to the aromatic ring as well as steric freedom [54, 55]. Clearly, the para-substituted hydroxyl group was observed to be highly proficient in radical scavenging activity. Also, the hydroxyl groups serve out to stabilizing the antioxidant radical formed [56-58]. Literature reported that the presence of hydroxyl group ortho-to phenol causes stabilization to the radical formed and consequently a lowering in hydrogen bond dissociation and hence showed an increase in antioxidant capacity [56]. The causes of free radical-scavenging activity powerful of taxifolin are firstly; its conjugation structures and resonance stability of its phenolic rings. Accordingly, two radicals are probable by the removal of a hydrogen atom from the corresponding orto-or meta-OH groups from taxifolin molecule, thus the hydroxyl groups at positions-C-3', 4' in flavonoids molecule are the most important strong antioxidant active place.

Table 6: Free radical scavenging antioxidant activity (DPPH) of the isolated compounds (1-7) from M. oleifera leaves

\begin{tabular}{ll}
\hline Compound & ${ }^{\mathbf{1} D P P H} \mathbf{S C}_{\mathbf{5 0}}[\boldsymbol{\mu g} / \mathbf{m l}]$ \\
\hline 1 & $8.45 \pm 1.84$ \\
2 & $6.25 \pm 1.24$ \\
3 & $2 \mathrm{~N} . \mathrm{D}$. \\
4 & $5.75 \pm 1.29$ \\
5 & $4.35 \pm 1.79$ \\
6 & $10.65 \pm 0.95$ \\
7 & $\mathrm{~N} . \mathrm{D}$. \\
Ascorbic acid & $8.25 \pm 1.45$ \\
\hline
\end{tabular}

All data are expressed as mean \pm standard deviation $(\mathrm{n}=3)$, DPPH values are expressed as $\mu \mathrm{g}$ compound $/ \mathrm{ml}(\mu \mathrm{g} / \mathrm{ml}),{ }^{1} \mathrm{SC} \mathrm{C}_{50}$ : Sample concentration required for scavenging of $50 \%$ of the free radical, ${ }^{2} \mathrm{~N}$. D.: Not detected. 


\section{CONCLUSION}

Our study presented seven compounds, most of the isolated compounds were observed to be a powerful antioxidant and antiradical agents in different in vitro bioassays when contrasted with standard antioxidant compounds. This study is a good indicator for the ability to use the Egyptian M. oleifera leaves as a good source of naturally occurring antioxidant agents and also it's possible to safely use in medicinal and nutritional supplements.

\section{CONFLICTS OF INTERESTS}

All authors have none to declare

\section{REFERENCES}

1. Anwar F, Latif S, Ashraf M, Gilani AH. Moringa oleifera: a food plant with multiple medicinal uses. Phytother Res 2007;21:17-25.

2. Makkar HPS, Becker K. Nutritional value and antinutritional components of whole and extracted Moringa oleifera leaves. Anim Feed Sci Technol 1996;63:211-28.

3. Makkar HPS, Becker K. Nutrients and anti-quality factor in different morphological part of Moringa oleifera tree. J Agric Sci 1997;128:211-322.

4. Dhakar RC, Maurya SD, Pooniya BK, Bairwa N, Gupta M. Moringa: the herbal gold to combat malnutrition. Chron Young Sci 2011;2:119-25.

5. Faizi S, Sumbul S, Versiani MA, Saleem R, Sana A, Siddiqui H. GC/GCMS analysis of the petroleum ether and dichloromethane extracts of Moringa oleifera roots. Asia Pac J Trop Biomed 2014;4:650-4

6. Kumar A, Pari L. Antioxidant action of Moringa oleifera Lam (drumstick) against antitubercular drugs induced lipid peroxidation in rats. J Med Food 2003;6:255-9.

7. Sharma R, Singh VJ. In vivo antioxidant activity of Moringa oleifera leaf and pod extracts against carbon tetrachloride induced liver damage in albino mice. J Chem Pharm Res 2010;2:275-83.

8. Kumar V, Pandey N, Mohan N, Singh RP. Antibacterial and antioxidant activity of a different extract of Moringa oleifera leaves an in vitro study. Int J Pharm Sci Rev Res 2012;12:89-94.

9. Guevara AP, Vargas C, Sakurai H. An antitumor promoter from Moringa oleifera Lam. Mutat Res 1999;440:181-8.

10. Nikkon F, Saud ZA, Rahman MH, Haque ME. In vitro antimicrobial activity of the compound isolated from the chloroform extract of Moringa oleifera Lam. Pakistan J Biol Sci 2003;6:1888-90.

11. Pari L, Kumar NA. Hepatoprotective activity of Moringa oleifera on antitubercular drug induced liver damage in rats. J Med Food 2002;5:171-7.

12. Ezejindu DN, Udemezue 00, Chinweife KC. Hepatoprotective effects of Moringa oleifera extract on liver of Wistar rats. Int J Res Med Health Sci 2014;3:23-7.

13. Roy SK, Chandra K, Ghosh K, Mondal S, Maiti D, Ojha AK, et al. Structural investigation of a heteropolysaccharide isolated from the pods (fruits) of Moringa oleifera (Sajina). Carbohyd Res 2007;342:2380-9.

14. Manguro LO, Lemmen P. Phenolics of Moringa oleifera leaves. Nat Prod Res 2007;21:56-68.

15. Yammuenart D, Chavasiri W, Pongrapeeporn K. Chemical constituents of Moringa oleifera Lam. Sci Forum 2008;3:80-1.

16. Bennett RN, Mellon FA, Foidl N, Pratt JH, Dupont MS, Perkins $\mathrm{L}$, et al. Profiling glucosinolates and phenolics in vegetative and reproductive tissues of the multi-purpose trees Moringa oleifera L. (horseradish tree) and Moringa stenopetala L. J Agric Food Chem 2003;51:3546-53.

17. Siddhuraju P, Becker K. Antioxidant properties of various solvent extracts of total phenolic constituents from three different agroclimatic origins of drumstick tree (Moringa oleifera Lam.) leaves. J Agric Food Chem 2003;51:2144-55.

18. Ghareeb MA, Saad AM, Abdel-Aleem AH, Abdel-Aziz MS, Hamed MM, Hadad AH. Antioxidant, antimicrobial, cytotoxic activities and biosynthesis of silver and gold nanoparticles using Syzygium jambos leave growing in Egypt. Der Pharm Chem 2016;8:277-86.
19. Ghareeb MA, Ahmed WS, Refahy LA, Abdou AM, Hamed MM, Abdel-Aziz MS. Isolation and characterization of the bioactive phenolic compounds from Morus alba leaves growing in Egypt. Pharmacologyonline 2016;3:157-67.

20. Hamed MM, Refahy LA, Abdel-Aziz MS. Assessing the bioactivity and antioxidative properties of some compounds isolated from Abutilon hirtum (lam.). Asian J Pharm Clin Res 2017;10:333-40.

21. El-Sayed MM, Maher AM, Hanan AE, Sayed AE, Eman AE, Ghareeb MA. Bio-guided isolation and structure elucidation of antioxidant compounds from the leaves of Ficus sycomorus. Pharmacologyonline 2010;3:317-32.

22. Ghareeb MA, Saad AM, Abdou AM, Refahy LA, Ahmed WS. A new kaempferol glycoside with antioxidant activity from Chenopodium ambrosioides growing in Egypt. Orient J Chem 2016;32:3053-61.

23. Wilbrandt W. Behrens methods for calculation of $\mathrm{LD}_{50}$. Arzneimittelforschung 1952;2:501-3.

24. Sharma RK, Chatterji S, Rai DK, Mehta S, Rai PK, Singh RK, et al. Antioxidant activities and phenolic contents of the aqueous extracts of some Indian medicinal plants. J Med Plants Res 2009;3:944-8.

25. Kalpna R, Mital K, Sumitra C. Vegetable and fruit peels as a novel source of antioxidants. J Med Plants Res 2011;5:63-71.

26. Sreelatha S, Padma PR. Antioxidant activity and total phenolic content of Moringa oleifera leave in two stages of maturity. Plant Foods Hum Nutr 2009;64:303-11.

27. El-Awady MA, Hassan MM, Abdel-Hameed ES, Gaber A. Comparison of the antioxidant activities, phenolic and flavonoids contents of the leaves-crud extracts of Moringa peregrina and Moringa oleifera. Int J Biosci 2016;8:55-62.

28. Mohamed MA, Hamed MM, Abdou AM, Ahmed WS, Saad AM. Antioxidant and cytotoxic constituents from Wisteria sinensis. Molecules 2011;16:4020-30.

29. Hsu FH, Houng JY, Chang $\mathrm{CL}, \mathrm{Wu} \mathrm{CC}$, Chang FR, Wu YC. Antioxidant activity, cytotoxicity, and DNA information of glossogyne tenuifolia. J Agric Food Chem 2005;53:6117-25.

30. Mohamed MA, Abdou AM, Hamed MM, Saad AM. Characterization of bioactive phytochemical from the leaves of Vitex trifolia. Int J Pharm Appl 2012;3:419-28.

31. Ghareeb MA, Hussein AS, Hassan MFM, Laila AR, Mona AM, Amal MS. Antioxidant and cytotoxic activities of Tectona grandis Linn. leaves. Int J Phytopharmacol 2014;5:143-57.

32. El-Sayed MM, Maher ME, Eman AE, Ghareeb MA. Total phenolic contents and antioxidant activities of Ficus sycomorus and Azadirachta indica. Pharmacologyonline 2009;3:590-602.

33. Sadraei H, Asghari G, Farahnaki F. Assessment of hydroalcoholic extract of seeds and leaves of Moringa peregrina on ileum spasm. Res Pharmacol Sci 2015;10:252-8.

34. Chang WC, Kim SC, Hwang SS, Choi BK, Ahn HJ, Lee MY, et al. Antioxidant activity and free radical scavenging capacity between Korean medicinal plants and flavonoids by assayguided comparison. Plant Sci 2002;163:1161-8.

35. Soler-Rivas C, Espin JC, Wichers HJ. An easy and fast test to compare total free radical scavenger capacity of foodstuffs. Phytochem Anal 2000;11:330-8.

36. Huang DJ, Lin CD, Chen HJ, Lin YH. Antioxidant and antiproliferative activities of sweet potato (Ipomoea batatas [L.] Lam 'Tainong 57') constituents. Bot Bull Acad Sinica 2005;45:179-86.

37. Saad AM, Abdel-Aleem AH, Ghareeb MA, Hamed MM, AbdelAziz MS, Hadad AH. In vitro antioxidant, antimicrobial and cytotoxic activities and green biosynthesis of silver and gold nanoparticles using Callistemon citrinus leaf extract. J Appl Pharm Sci 2016;6:277-86.

38. Adedapo AA, Mogbojuri OM, Emikpe BO. Safety evaluations of the aqueous extract of the leaves of Moringa oleifera in rats. J Med Plants Res 2009;3:586-91.

39. Chivapat $S$, Sincharoenpokai P, Saktiyasuthorn N, Shuaprom A, Thongsrirak P, Sakpetch A, et al. Acute and chronic toxicity of Moringa oleifera Linn leaves extracts. Thai J Vet Med 2011;41:417-24. 
40. Ojo NA, Igwenagu E, Badau SJ, Sambo N, Ngulde SI, Adawaren EO, et al. Acute toxicity and effect of aqueous extract of Moringa oleifera leaves on organs and tissues in rats. J Environ Issues Agric Dev Count 2013;5:41-50.

41. Okumu MO, Mbaria JM, Kanja LW, Gakuya DW, Kiama SG, Ochola FO, et al. Acute toxicity of the aqueous methanolic Moringa oleifera (Lam) leaf extract on female Wistar albino rats. Int J Basic Clin Pharmacol 2016;5:1856-61.

42. Kasolo JN, Bimenya GS, Ojok L, Ogwal-okeng JW. Phytochemicals and acute toxicity of Moringa oleifera roots in mice. J Pharm Phytother 2011;3:38-42.

43. Kasolo JN, Bimenya GB, Ojok L, Ogwal-Okeng JW. Sub-acute toxicity evaluation of Moringa oleifera leaves aqueous and ethanol extracts in swiss albino rats. Int J Med Plant Res 2012;1:075-81.

44. Reddy YRR, Lokanatha O, Ratnam KSVP, Reddy CS, Raju IN, Reddy CD. Acute and subacute toxicity of Moringa oleifera stem bark extract in Swiss albino mice. Int J Life Sci Biotechnol Pharm Res 2013;2:74-82.

45. Lu Y, Foo Y. Flavonoid and phenolic glycosides from Salvia officinalis. Phytochemistry 2000;55:263-7.

46. Mabry TJ, Markham KR, Thomas MB. In: The Systematic Identification of Flavonoids. Springer-Verlag, BerlinHeidelberg-New York; 1970. p. 354.

47. Faizi S, Siddiqui BS, Saleem R, Siddiqui S, Aftab K, Gilani AH. Fully acetylated carbamate and hypotensive thiocarbamate glycosides from Moringa oleifera. Phytochemistry 1995;38:957-63.

48. Maurya A, Gupta S, Srivastava SK. Preparative isolation of bioactive nitrile glycoside "Niazirin" from the fruits of Moringa oleifera using fast centrifugal partition chromatography. Separ Sci Technol 2011;46:1195-9.
49. Delnavazi MR, Mohammadifar F, Rustaie A, Aghaahmadi M, Yassa N. Phytochemical constituents, antioxidant activity and toxicity potential of Phlomis olivieri Benth. Res J Pharmacogn 2016;3:9-15.

50. Nikkon F, Hasan S, Salam KA, Mosaddik MA, Khondkar P, Haque $\mathrm{ME}$, et al. Benzylcarbamothioethionate from root bark of Moringa oleifera Lam, and its toxicological evaluation. Lat Am Caribb Bull Med Arom Plants 2009;8:130-8.

51. Rice-Evans CA, Miller NJ, Paganga G. Structure-antioxidant activity relationships of flavonoids and phenolic acids. Free Radical Biol Med 1996;20:933-56.

52. Mazzone G, Malaj N, Russo N, Toscano M. Density functional study of the antioxidant activity of some recently synthesized resveratrol analogues. Food Chem 2013;141:2017-24.

53. Milic BLj, Djilas SM, Canadanovic-Brunet JM. Antioxidative activity of phenolic compounds on the metal-ion breakdown of lipid peroxidation system. Food Chem 1998;61:443-7.

54. Galato D, Ckless K, Susin MF. Antioxidant capacity of phenolic and related compounds: correlation among electrochemical, visible spectroscopy methods and structure-antioxidant activity. Redox Rep 2001;6:243-50.

55. Lu Z, Nie G, Belton PS. Structure-activity relationship analysis of antioxidant ability and neuroprotective effect of gallic acid derivatives. Neurochem Int 2006;48:263-74.

\section{How to cite this article}

- $\quad$ Manal Mortady Hamed, Aboelfetoh Mohamed Abdalla, Mosad Ahmed Ghareeb, Said Abdelhalim Saleh. Chemical constituents, in vitro antioxidant activity, oral acute toxicity and $\mathrm{LD}_{50}$ determination of Moringa oleifera leave. Int J Pharm Pharm Sci 2017;9(5):240-247. 